\title{
GTPase KRas
}

National Cancer Institute

\section{Source}

National Cancer Institute. GTPase KRas. NCI Thesaurus. Code C17383.

GT Pase KRas (189 aa, $21 \mathrm{kDa}$ ) is encoded by the human KRAS gene. This protein is involved in the regulation of GTP metabolism and in signaling. 